\title{
Preparation of a Master Fe-Cu Alloy by Smelting of a Cu-Bearing Direct Reduction Iron Powder
}

\author{
Liaoting Pan, Deqing Zhu, Zhengqi Guo * and Jian Pan \\ School of Mineral Processing and Bioengineering, Central South University, Changsha 410083, China; \\ plt6299@126.com (L.P.); dqzhu@csu.edu.cn (D.Z.); pjcsu@csu.edu.cn (J.P.) \\ * Correspondence: guozqcsu@csu.edu.cn; Tel.: +86-185-7313-1417; Fax: +86-731-8883-6942
}

Received: 13 May 2019; Accepted: 18 June 2019; Published: 21 June 2019

\begin{abstract}
Generally, the Cu-bearing direct reduction iron powder (CBDRI) obtained from a direct reduction-magnetic separation process of waste copper slag contains a high content of impurities and cannot be directly used to produce $\mathrm{Cu}$-bearing special steel. In this paper, further smelting treatment of CBDRI was conducted to remove its impurities (such as $\mathrm{S}, \mathrm{SiO}_{2}, \mathrm{Al}_{2} \mathrm{O}_{3}, \mathrm{CaO}$ and $\mathrm{MgO}$ ) and acquire a high-quality $\mathrm{Fe}-\mathrm{Cu}$ master alloy. The results show that the $\mathrm{Fe}-\mathrm{Cu}$ master alloy, assaying $95.9 \% \mathrm{Fe}, 1.4 \% \mathrm{Cu}$ and minor impurities, can be obtained from the smelting process at $1550{ }^{\circ} \mathrm{C}$ for 40 min with 1.0 basicity. Meanwhile, the corresponding iron and copper recoveries are $98.6 \%$ and $97.2 \%$, respectively. Theoretical calculations and experimental results show that appropriate basicity $(0.9 \sim 1.1)$ is beneficial for the recovery of $\mathrm{Fe}$ and $\mathrm{Cu}$ from a thermodynamic viewpoint due to the excellent fluidity of the slag in this basicity range. Moreover, the mechanism of desulfurization was revealed by calculating the sulfide capacity and the desulfurization reaction kinetics. Increasing the binary basicity of the slag benefits both the sulfide capacity and diffusion coefficient of the sulfur in the molten slag, resulting in higher desulfurization efficiency and lower $\mathrm{S}$ content in the master alloy.
\end{abstract}

Keywords: Cu-bearing direct reduction iron; smelting; Cu-bearing steel; basicity; sulfide capacity; desulfurization

\section{Introduction}

Cu-bearing steel is characterized by high strength, excellent corrosion resistance and high antibacterial ability [1-4]. Based on this characterization, many kinds of Cu-bearing steels, such as weathering steel, antibacterial stainless steel and high-strength steel (HSAL serials), have been rapidly developed in recent years [5-7]. Generally, conventional Cu-bearing steel production methods require the addition of electrolytic copper to adjust the copper content in the products [8-10]. Unfortunately, with the depletion of high-grade copper mineral resources in the world, the production costs for electrolytic copper remains high. This problem could ultimately lead to higher production costs for $\mathrm{Cu}$-bearing steel. However, low-cost ferroalloy ( $\mathrm{Fe}-\mathrm{Cu}$ alloy) may replace electrolytic copper in the production of the $\mathrm{Cu}$-bearing steels, which provides the possibility of innovation lowering technology costs.

Copper smelting slag typically contains $40 \% \mathrm{Fe}$ and $1 \% \mathrm{Cu}$ and can be considered as an important secondary resource for utilization [11]. Recently, researchers have proposed processes to recover valuable metals from copper slag [12-17]. However, those processes mainly focused on Cu recovery while totally neglecting Fe recovery. Direct reduction process, as a novel process, was developed to treat the copper slag $[8,10,18-22]$. In this process, the iron oxides and copper bearing minerals were reduced to metallic iron and copper. The metallic copper dissolves into metallic Fe lattices to form a $\mathrm{Fe}-\mathrm{Cu}$ solid solution (Fe-Cu alloy). The $\mathrm{Fe}-\mathrm{Cu}$ solid solution can then undergo subsequent grinding and magnetic separation processes. Therefore, this process can fulfil the comprehensive recovery of $\mathrm{Fe}$ and $\mathrm{Cu}$ from copper slag and attain $\mathrm{Fe}-\mathrm{Cu}$ direct reduction iron powder (CBDRI). CBDRI could 
potentially substitute for scrap steel and electrolytic copper in the production of Cu-bearing steel and may lead to lower costs for steel production. However, most CBDRI is not suitable for being directly used in steel production due to its high impurity concentration $\left(\mathrm{SiO}_{2}, \mathrm{Al}_{2} \mathrm{O}_{3}, \mathrm{CaO}, \mathrm{MgO}\right.$ and $\mathrm{S})$, therefore, a necessary extra smelting step to remove those impurities and obtain a higher $\mathrm{Fe}-\mathrm{Cu}$ alloy purity is indispensable. There are few investigations, however, on CBDRI for the production of $\mathrm{Cu}$-bearing steel master alloy via electric furnace smelting.

CBDRI has been successfully prepared from copper smelting slag by a direct reduction-magnetic separation process as reported in our earlier paper [10]. The aim of this research is to produce a high-quality $\mathrm{Fe}-\mathrm{Cu}$ master alloy from CBDRI by a smelting process and directly use the master alloy as the raw material to produce $\mathrm{Cu}$-bearing steel by an electric arc furnace to replace part of the electrolytic copper and scrap steel. Additionally, the desulfurization behavior and its mechanism in the smelting process were revealed in this work.

\section{Experimental}

\subsection{Raw Materials}

The Fe-Cu direct reduction iron powder (CBDRI)used in this study was obtained from the direct reduction and magnetic separation of copper smelting slag. The chemical mass composition of CBDRI shown in Table 1 and demonstrate that CBDRI contains $90.33 \% \mathrm{Fe}$ and $1.29 \% \mathrm{Cu}$, which are potential materials for the preparation of copper bearing steel. Some undesirable impurities, such as $\mathrm{SiO}_{2}$, $\mathrm{Al}_{2} \mathrm{O}_{3}, \mathrm{CaO}$, and $\mathrm{MgO}$, are also found in the CBDRI. In particular, the $\mathrm{S}$ content in CBDRI is as high as $0.3 \%$, which is extremely harmful to the production of Cu-bearing steel. The smelting treatment of the CBDRI is necessary to ensure the quality of the alloy. Furthermore, the size distribution of CBDRI presented in Figure 1 shows that the CBDRI is very fine, with over $90 \%$ below $0.074 \mathrm{~mm}$.

Table 1. Chemical compositions of CBDRI (wt \%).

\begin{tabular}{ccccccccccc}
\hline $\mathbf{F e}$ & $\mathbf{C u}$ & $\mathbf{S}$ & $\mathbf{M F e}$ & $\mathrm{SiO}_{2}$ & $\mathrm{Al}_{2} \mathbf{O}_{3}$ & $\mathbf{C a O}$ & $\mathbf{M g O}$ & $\mathbf{N a}_{2} \mathbf{O}$ & $\mathbf{C}$ & $\mathbf{P}$ \\
\hline 90.33 & 1.29 & 0.30 & 87.54 & 3.62 & 0.56 & 1.09 & 0.29 & 0.07 & 0.78 & 0.012 \\
\hline
\end{tabular}

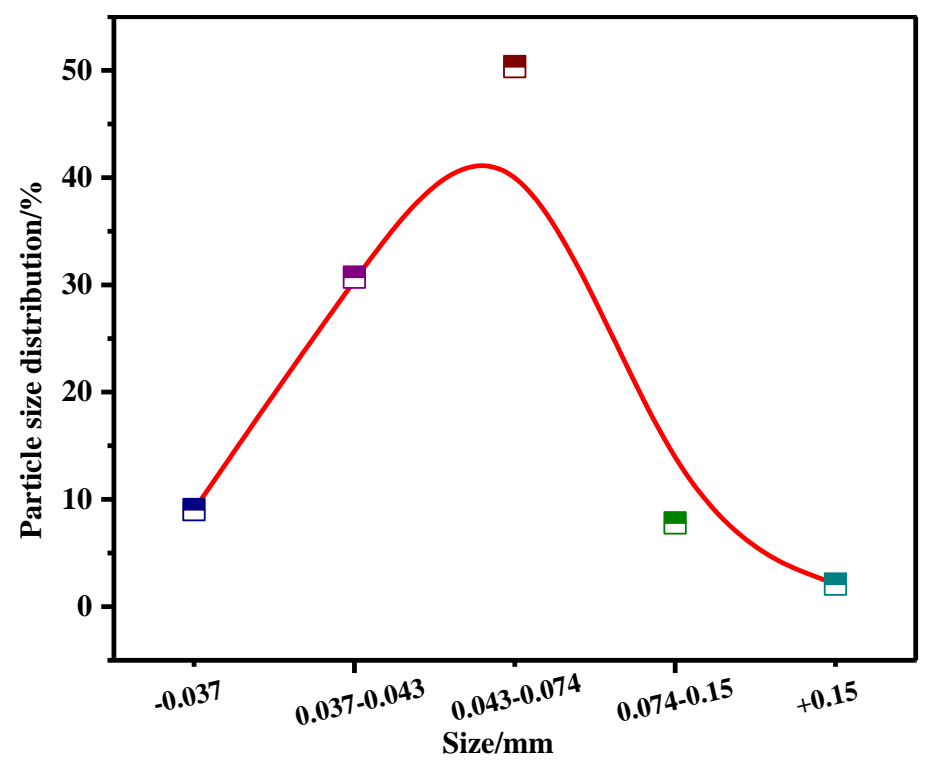

Figure 1. Size distribution of CBDRI.

The chemical composition of limestone is shown in Table 2. Limestone containing $55.73 \%$ of $\mathrm{CaO}$ was used as both a flux and desulfurizer to adjust the binary basicity (ratio of $\mathrm{CaO} / \mathrm{SiO}_{2}$ ) and remove sulfur in the smelting process. Its particle size was less than $0.074 \mathrm{~mm}$. 
Table 2. Chemical compositions of limestone(wt \%).

\begin{tabular}{cccccccc}
\hline $\mathrm{CaO}$ & $\mathrm{Al}_{2} \mathrm{O}_{3}$ & $\mathrm{SiO}_{2}$ & $\mathbf{M g O}$ & $\mathbf{P}$ & $\mathbf{S}$ & $\mathrm{MnO}$ & LOI \\
\hline $\mathbf{5 5 . 7 3}$ & 1.19 & 4.13 & 2.05 & 0.001 & 0.001 & 0.02 & 41.52 \\
\hline
\end{tabular}

\subsection{Experimental Methods}

\subsubsection{Smelting Process}

The smelting tests were performed under a controlled environment in a vertical $\mathrm{MoSi}_{2}$ heating furnace (schematic diagram of the smelting furnace is shown in Figure 2). The proportion integral differential (PID)temperature control programme in the furnace was used to limit the temperature fluctuation range to $\pm 5^{\circ} \mathrm{C}$. In each test, $30 \mathrm{~g}$ of CBDRI were mixed uniformly with the required amount of limestone. The mixtures were then loaded into a $50 \mathrm{~mL}$ corundum crucible. When the furnace temperature was raised to the smelting temperature $\left(1515 \sim 1600^{\circ} \mathrm{C}\right)$, the crucible was quickly placed into the heating zone of the furnace and smelted for a given period of time (10 60min) under a $\mathrm{N}_{2}$ atmosphere. At the end of smelting, the crucible was taken out of the furnace and quickly cooled under the cover via coke breeze. Finally, the crucible was broken to separate and weigh the $\mathrm{Fe}-\mathrm{Cu}$ alloy and slag carefully for sample preparation. The samples were then prepared to assay the chemical compositions.

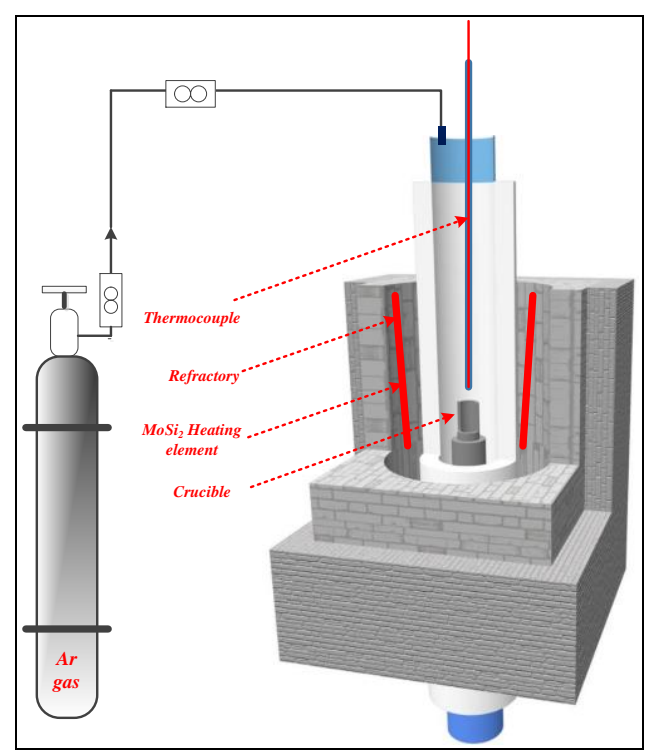

Figure 2. Schematic diagram of the smelting furnace.

The recovery rate of iron and $\mathrm{Cu} \eta$ was calculated from Equation (1):

$$
\eta=\frac{M_{1} \times T M_{1}}{M_{0} \times T M_{0}} \times 100 \%
$$

where $\eta$ is the recovery rate of $\mathrm{Fe}$ or $\mathrm{Cu} ; M_{1}$ is the mass of the $\mathrm{Fe}-\mathrm{Cu}$ master alloy; $T M_{1}$ is the grade of $\mathrm{Fe}$ or $\mathrm{Cu}$ in the master alloy; $M_{0}$ is the mass of CBDRI; $T M_{0}$ is the grade of $\mathrm{Fe}$ or $\mathrm{Cu}$ in CBDRI.

\subsubsection{Analytic Tests}

A thermodynamic package FactSage (Version 7.0) software (GTT-Technologies, Herzogenrath, Germany) was used to calculate the phase diagram of $\mathrm{Fe}-\mathrm{Cu}-\mathrm{C}, \mathrm{SiO}_{2}-\mathrm{Al}_{2} \mathrm{O}_{3}-\mathrm{CaO}-\mathrm{MgO}$ and the viscosity of the molten slag. The phase compositions of the samples were investigated using an $\mathrm{X}$-ray diffractometer (XRD, D/max 2550 PC, Rigaku Co., Ltd, Tokyo, Japan). Microstructure analyses of 
master alloy were observed by a Leica DMLP optical microscopy, FEI Quata-200 scanning electron microscope (SEM, TESCAN, MIRA3 LMU, Brno, Czech Republic) and an EDAX energy dispersive $X$-ray spectrometer (EDS). The SEM images were recorded in backscatter electron modes operating in the low vacuum mode at 0.5 Torr and $20 \mathrm{keV}$.

\section{Results and Discussion}

\subsection{Thermodynamics Calculations of Smelting Process}

The thermodynamics calculations for the molten slag and alloy in smelting process were conducted by FactSage 7.0 to analyse the feasibility for separation between the slag and master alloy. The quaternary phase diagram of the $\mathrm{CaO}-\mathrm{MgO}-\mathrm{SiO}_{2}-\mathrm{Al}_{2} \mathrm{O}_{3}$ primary slag is presented in Figure 3 and shows that the primary slag possesses the appropriate liquidus temperature at approximately $1450{ }^{\circ} \mathrm{C}$.

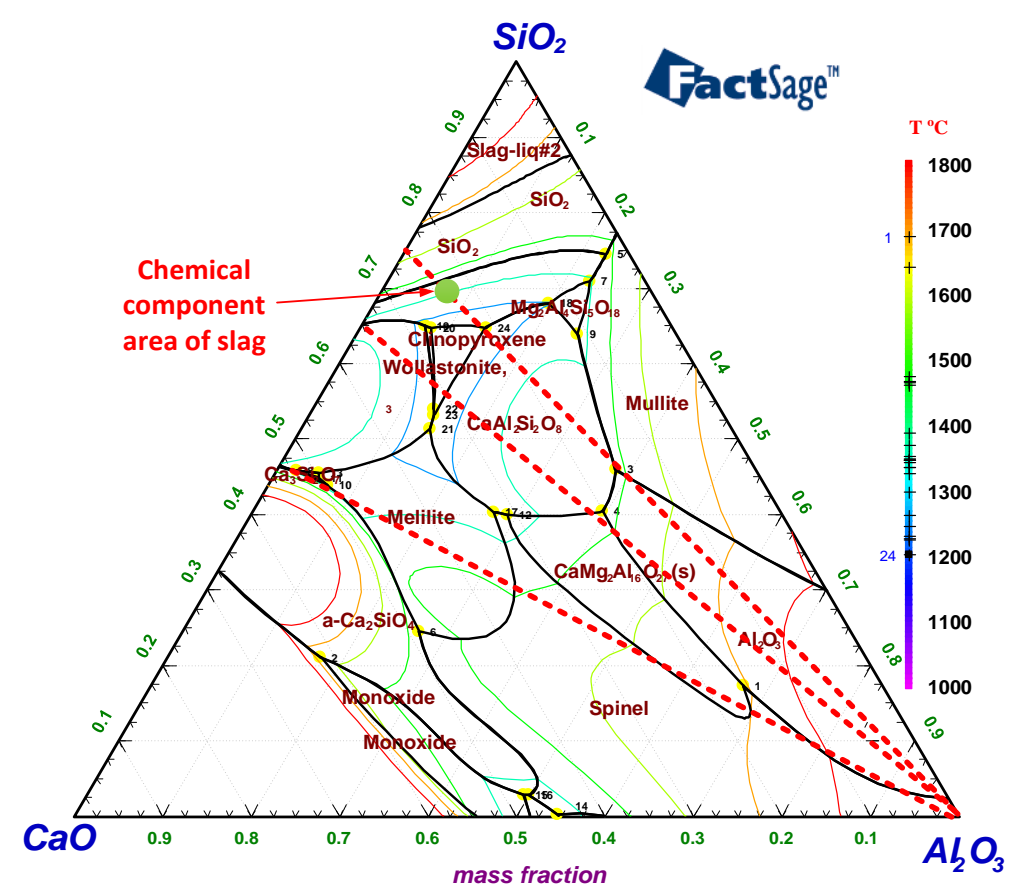

Figure 3. Phase diagram of $\mathrm{SiO}_{2}-\mathrm{Al}_{2} \mathrm{O}_{3}-\mathrm{CaO}$ with $\mathrm{MgO}=5.22 \%$.

In addition, the liquid projection of the ternary alloy was carried out; the results are shown in Figure 4. The liquidus temperature of this ternary alloy was near $1450{ }^{\circ} \mathrm{C}$. Based on the Figures 3 and 4 , the smelting temperature should be $1500 \sim 1550{ }^{\circ} \mathrm{C}$ to ensure a good separation between alloy and slag and to keep a superheated temperature range.

\subsection{Smelting Process of CBDRI}

As shown in Table 1, iron and copper, as the main valuable metals in DRI, should be considered first for recovery. Therefore, the experiments on the effect of smelting conditions on Fe and Cu recovery and quality of the master alloy were carried out systematically. 


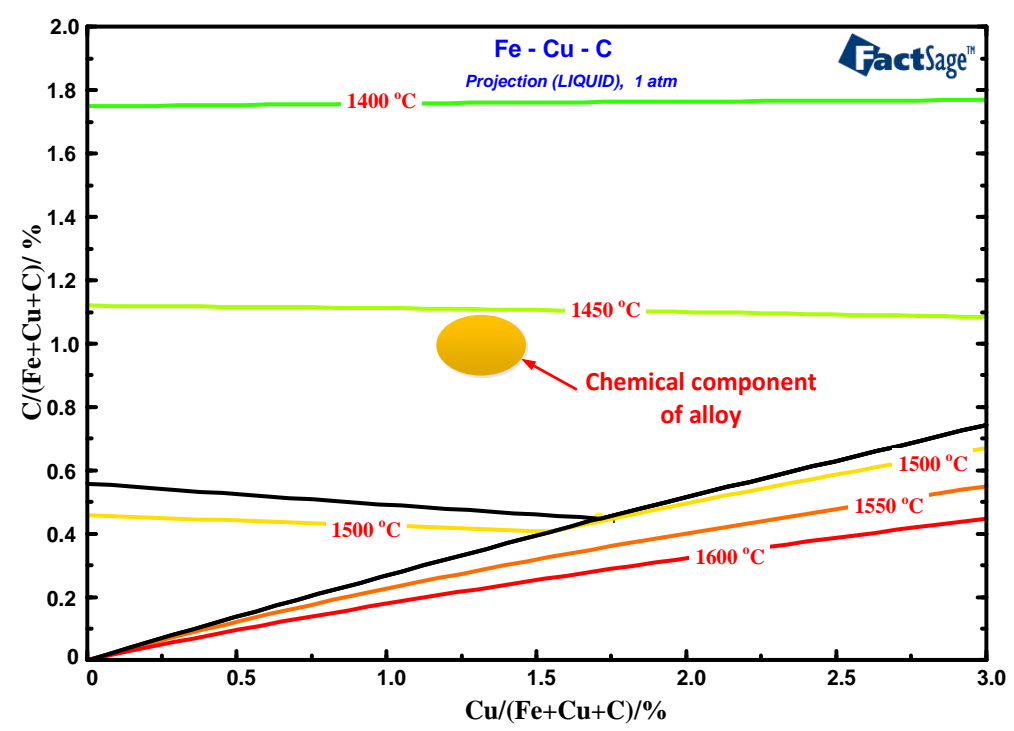

Figure 4. Phase diagram of $\mathrm{Fe}-\mathrm{Cu}-\mathrm{C}$.

\subsubsection{Effect of Smelting Temperature}

Undoubtedly, smelting temperature has a significant effect on the smelting process. The effect of the smelting temperature on $\mathrm{Fe}$ and $\mathrm{Cu}$ recovery and the quality of the master alloy was investigated. The results (Figure 5) show that with an increase in the smelting temperature, the Fe and Cu recovery is elevated and maintained approximately $96 \%$. Additionally, the S content of the master alloy decreased sharply and was maintained at $0.13 \%$. When the smelting temperature was over $1550{ }^{\circ} \mathrm{C}$, all indexes slightly changed.

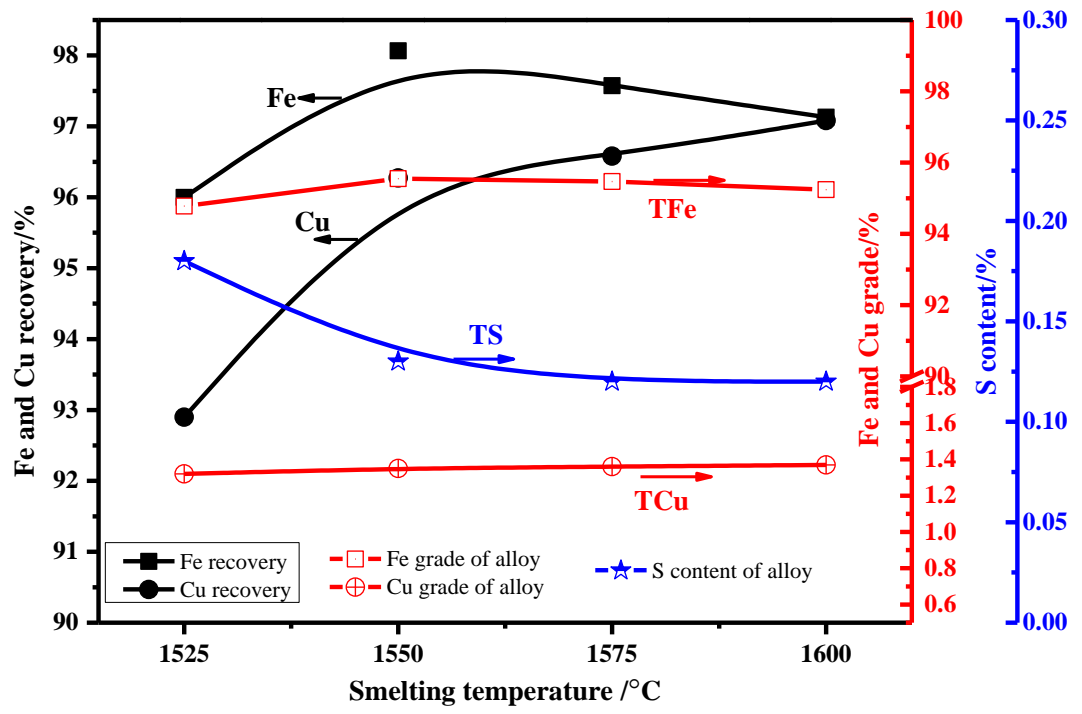

Figure 5. Effect of smelting temperature on Fe and $\mathrm{Cu}$ recovery and $\mathrm{S}$ removal (Smelting for $30 \mathrm{~min}$ with 0.7 binary basicity).

Generally, high temperatures are beneficial for improving the fluidity and decreasing the viscosity of molten slag, thus, resulting in a better settling and separation of the alloy particles. Therefore, the recovery of $\mathrm{Fe}$ and $\mathrm{Cu}$ increased as the temperature increased. In addition, the desulfurization reaction in the smelting process is an endothermic reaction, and higher temperatures are favourable for the desulfurization in view of the thermodynamics principles. Furthermore, based on dynamics theory, higher temperatures are also capable of promoting the diffusion of $\mathrm{S}^{2-}$ and $\mathrm{O}^{2-}$ ions from an alloy phase to a slag phase, and ultimately improve the desulfurization efficiency [23]. 
Therefore, the suitable smelting temperature for the smelting of CBDRI is suggested at $1550{ }^{\circ} \mathrm{C}$, which is in accordance with the thermodynamics analysis.

\subsubsection{Effect of Smelting Duration}

Smelting duration is believed to have a significant effect on the Fe and $\mathrm{Cu}$ recovery and the $\mathrm{Fe}-\mathrm{Cu}$ master alloy quality. Figure 6 shows the effect of the smelting duration on the Fe and $\mathrm{Cu}$ grade and recovery and the removal of $\mathrm{S}$. As the smelting duration increased from $10 \mathrm{~min}$ to $40 \mathrm{~min}$, the Fe and $\mathrm{Cu}$ recovery increased from $94.4 \%$ and $93.8 \%$ to $98.2 \%$ and $95.8 \%$, respectively. Correspondingly, the S content of the $\mathrm{Fe}-\mathrm{Cu}$ master alloy presented a decreasing trend from $0.18 \%$ to $0.1 \%$. Furthermore, the $\mathrm{Fe}$ and $\mathrm{Cu}$ grade of the master alloy changed slightly. When the smelting duration was further prolonged, the $\mathrm{Fe}$ and $\mathrm{Cu}$ recovery and $\mathrm{S}$ content were improved insignificantly.

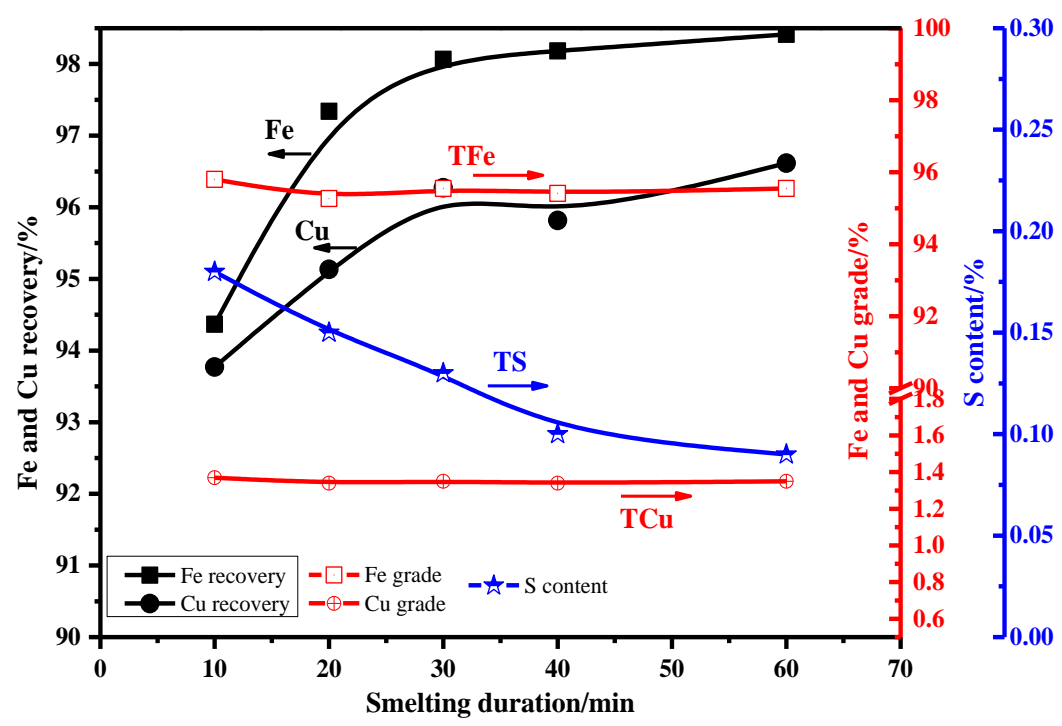

Figure 6. Effect of smelting time on $\mathrm{Fe}$ and $\mathrm{Cu}$ recovery and $\mathrm{S}$ removal (Smelting at $1550{ }^{\circ} \mathrm{C}$ with 0.7 basicity).

These results imply that the insufficient smelting time cannot ensure that the desulfurization reaction and the settling of the $\mathrm{Fe}-\mathrm{Cu}$ master alloy will carry out thoroughly, thus, leading to low metal recovery and poor alloy quality. Therefore, $40 \mathrm{~min}$ is appropriate for the simultaneous recovery of Fe and $\mathrm{Cu}$ and the removal of $\mathrm{S}$.

\subsubsection{Effect of Binary Basicity}

The influence of binary basicity on Fe and $\mathrm{Cu}$ recovery and the removal of $\mathrm{S}$ illustrated in Figure 7 and demonstrates that the binary basicity had a prominent effect on the smelting effect. Fe and $\mathrm{Cu}$ recovery first rose and then dropped as the binary basicity increased from 0.3 to 1.5. The recovery of $\mathrm{Fe}$ and $\mathrm{Cu}$ reached a maximum value of $98.6 \%$ and $97.2 \%$, respectively, at 1.0 basicity when the basicity changed from 0.3 to 1.5 . While the $\mathrm{S}$ content of the $\mathrm{Fe}-\mathrm{Cu}$ master alloy decreased from $0.150 \%$ to $0.039 \%$ during the binary basicity test. These results suggest that approximate basicity is in favour of the separation between the $\mathrm{Fe}-\mathrm{Cu}$ alloy and slag, and the removal of S.

The influence of binary basicity on the smelting process may be due to changes in slag viscosity. The contour map of the change in the viscosity at various temperatures and basicity's is shown in Figure 8 . The map illustrates that raising the temperature or approximately increasing the binary basicity is beneficial in improving the slag fluidity. It is worth noting that excessively high or low binary basicity results in a higher viscosity of the molten slag. Limestone can break the silicate and aluminosilicate bonds, and thereby increase the fluidity of the slag [24]. However, when the basicity is over 1.1 (e.g., the addition of limestone is excessive), less liquid phase (as seen in Figure 9) and 
more refractory solids, such as $\mathrm{Ca}_{2} \mathrm{SiO}_{4}$ (as seen in Figure 3), are generated, therefore, resulting in a molten slag with poor fluidity, which is detrimental to the smelting kinetics and phase separation. Ultimately, a basicity over 1.1 leads to low recovery of the Fe and $\mathrm{Cu}$. Moreover, the viscosity of the slag will tend to be at its minimum when the basicity is controlled in a range of $0.9 \sim 1.1$. Therefore, based on the experimental results, the optimum basicity is recommended at 1.0.

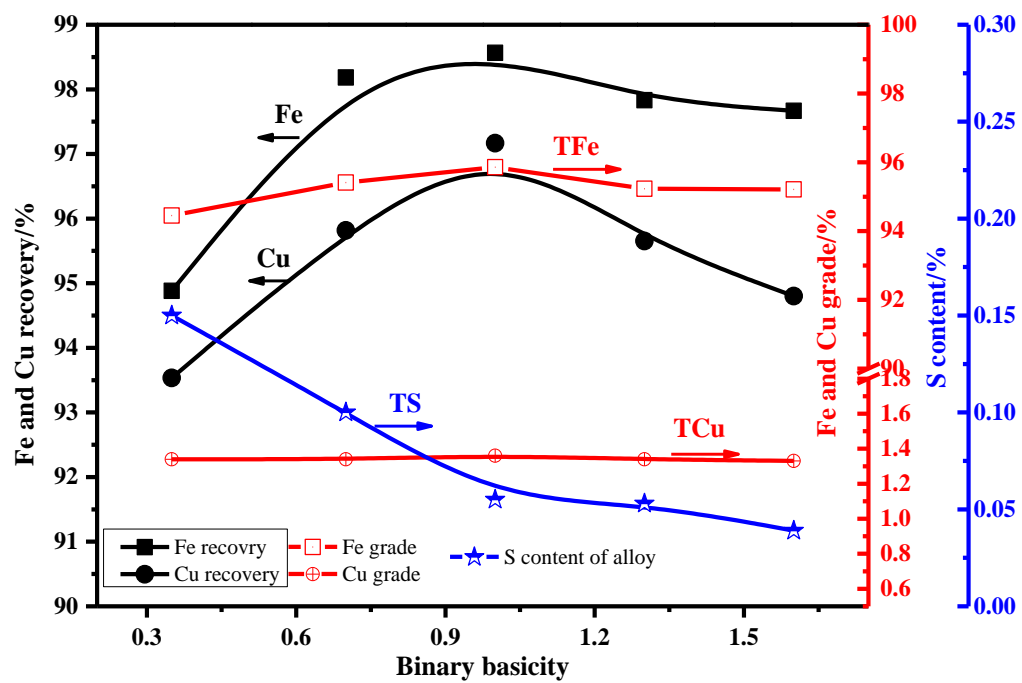

Figure 7. Effect of basicity on Fe and Cu recovery and $\mathrm{S}$ removal (Smelting at $1550{ }^{\circ} \mathrm{C}$ for $40 \mathrm{~min}$ ).

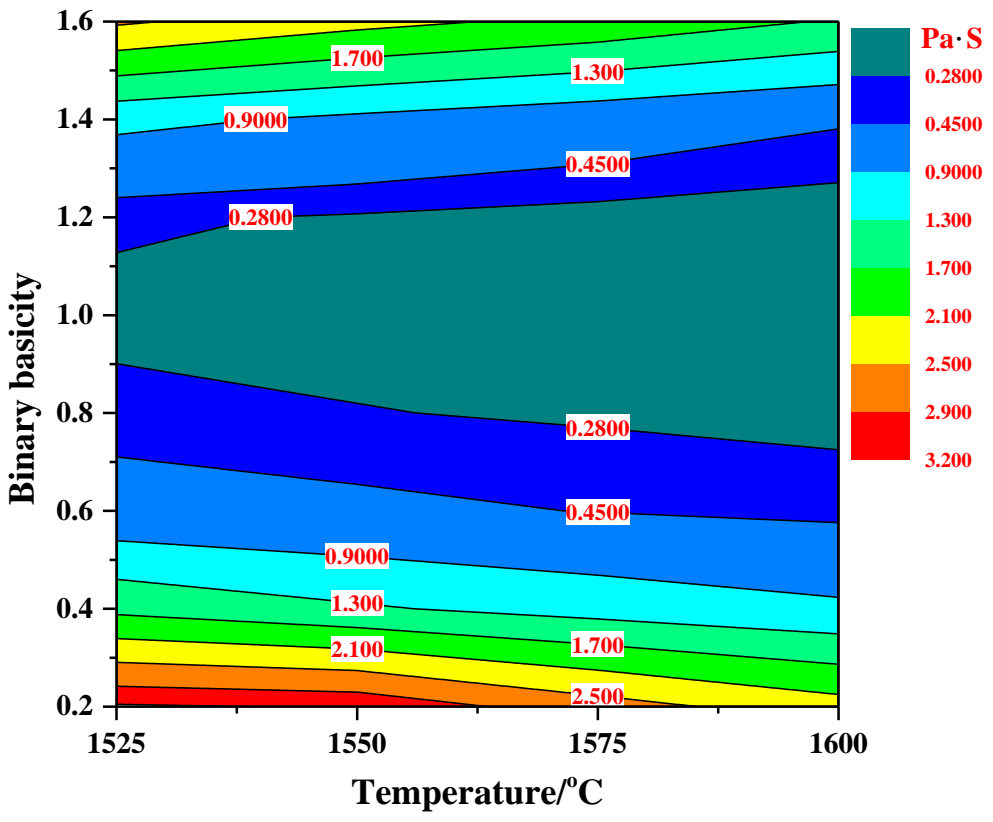

Figure 8. Contour map of viscosity change with various temperatures and basicity. 


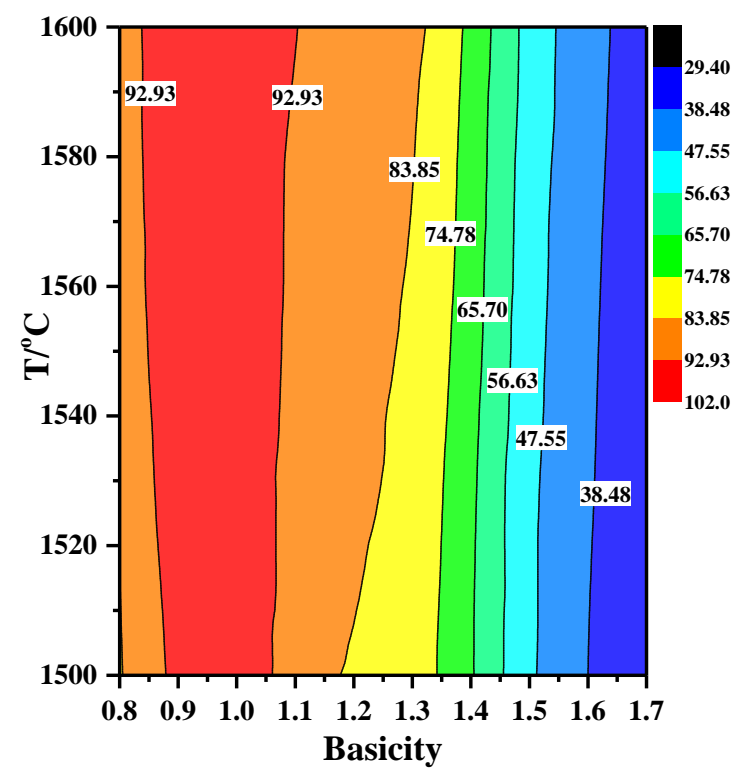

Figure 9. Effect of basicity and temperature on percentage of liquid phase in slag.

\subsection{Mechanism of Desulfurization}

It is well known that sulfur has adverse effects on the performance of steel products, such as its strength, ductility, and toughness [25]. As noted in the above experimental results, the basicity of the slag plays a significant role in desulfurization during the smelting process. To further reveal the mechanism of desulfurization, the sulfide capacity of the slag was calculated and the desulfurization kinetics were investigated.

\subsubsection{Sulfide Capacity (CS) of Slag}

The sulfide capacity (CS) and equilibrium distribution ratio of sulfur (LS) are important indicators for measuring the desulfurization capacity of a slag system. In this paper, the optical basicity model was introduced to predict the CS of various slags with different basicity's [23,26]. Optical basicity was calculated by the model shown in Equation (2):

$$
\Lambda=\sum_{B=1}^{n} \chi_{B} \Lambda_{B}
$$

where $\Lambda$ is optical basicity, $\chi_{B}$ is mole fraction of oxide cations, which is also defined as the fraction of each cationic charge neutralizing the negative charge.

Hence, the $\chi_{B}$ can be calculated as the following:

$$
\chi_{B}=n_{0} \chi_{B}^{\prime} / \sum n_{0} \chi_{B}^{\prime}
$$

where $\chi_{B}^{\prime}$ is the mole fraction of oxides, $n_{0}$ is the number of oxygen in each oxide component.

Combining Equation (2) with (3), Young's model was adopted to calculate the sulfide capacity in Equation (4), because it is an easy calculation, has a wide application scope and a high level of accuracy $[27,28]$.

$$
\lg C S=-13.913+42.84 \Lambda-\frac{11710}{T}-0.02223 w\left(\mathrm{SiO}_{2}\right)-0.02275 w\left(\mathrm{Al}_{2} \mathrm{O}_{3}\right)
$$

where $C S$ is the sulfide capacity of slag, $\Lambda$ is optical basicity; $w\left(\mathrm{SiO}_{2}\right)$ is mass fraction of $\mathrm{SiO}_{2}$ in slag, $w\left(\mathrm{Al}_{2} \mathrm{O}_{3}\right)$ is mass fraction of $\mathrm{Al}_{2} \mathrm{O}_{3}$ in slag. 
Based on Equation (4), the sulfide capacity of the various slags with different basicity's can be calculated and the results are shown in Figure 10. The temperature and basicity have a positive effect on the sulfide capacity of the slag. The sulfide capacity increases by increasing the basicity and temperature. This result means that the slag with the higher basicity has a greater ability to hold and remove more sulfide from the metal phase, resulting in an improvement in desulfurization efficiency and lower $\mathrm{S}$ content in the $\mathrm{Fe}-\mathrm{Cu}$ master alloy. The results of the theoretical calculations agree with the experiments shown in Figures 5 and 7.

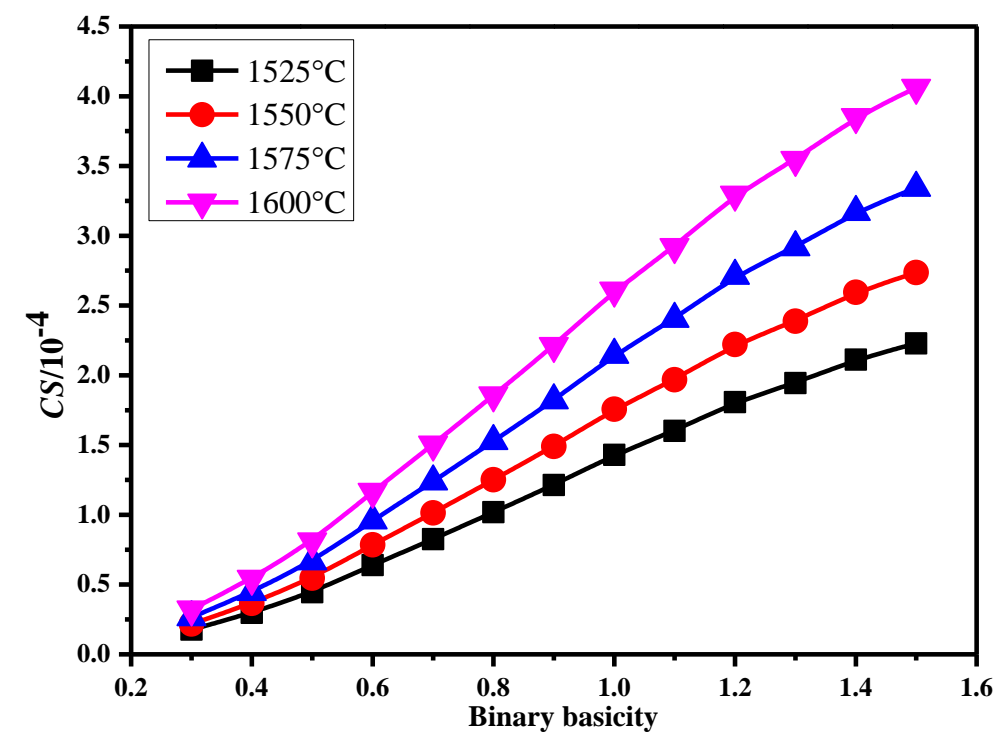

Figure 10. Effect of basicity and temperature on CS of the slag.

\subsubsection{Desulfurization Reaction Kinetics of Slag with Different Basicity}

As previous work has shown, the desulfurization process consists of five steps: (1) mass transfer of [S] from the metal phase to the interface between the metal and slag; (2) mass transfer of $\left(\mathrm{O}^{2-}\right)$ from the molten slag to the interface between the metal and slag; (3) an interfacial electrochemical reaction at the interface of the metal and slag; (4) mass transfer of the $\mathrm{S}^{2-}$ generated in interfacial chemical reaction from the interface to the molten slag; (5) mass transfer of $\mathrm{O}^{2-}$ generated in the interfacial chemical reaction from the interface to the molten metal $[28,29]$.

Compared with the diffusion steps, the rate of the electrochemical interfacial reaction is much faster under a high smelting temperature. In view of that, the overall desulfurization rate is controlled by the mass transfer. Moreover, the diffusion coefficient of $S$ is tens of times higher than that of $\mathrm{O}$, and the diffusion coefficient of sulfur in the metal is about two orders of magnitude larger than that in the slag phase [28-30]. Hence, the control process of the desulfurization reaction is the mass transfer of $S$ in the slag, which was also confirmed by previous work [28,30-32]. Based on this result, the desulfurization rate equation can be expressed as the following:

$$
-\frac{d[\% \mathrm{~S}]}{d t}=\frac{A}{V_{m}} \cdot K\left\{[\% \mathrm{~S}]-[\% S]^{*}\right.
$$

where $[\% \mathrm{~S}]$ is the $\mathrm{S}$ content of molten metal, $[\% \mathrm{~S}]^{*}$ is the $\mathrm{S}$ content of the metal-slag interface, $\mathrm{K}$ is the diffusion coefficient, $V \mathrm{~m}$ is the volume of molten metal, $A$ is the interface area.

By integrating Equation (5), the following rate formulas could be deduced as follows:

$$
\operatorname{In} \frac{[\% \mathrm{~S}]_{0}-[\% \mathrm{~S}]_{F}}{[\% \mathrm{~S}]_{t}-[\% \mathrm{~S}]_{F}}=k \frac{1}{H} t
$$


where $[\% \mathrm{~S}]_{0}$ is the $\mathrm{S}$ content in the molten metal at the initial stage, $[\% \mathrm{~S}] \mathrm{t}$ is the $\mathrm{S}$ content in the molten metal at a time $(t)$ during the reaction, $[\% \mathrm{~S}]_{\mathrm{F}}$ is the $\mathrm{S}$ content in the molten metal under equilibrium conditions, $\mathrm{H}$ is the height of the molten metal, $\mathrm{k}$ is the diffusion coefficient, $t$ is the reaction time.

Figure 11 shows the change in sulfur content with time and slag basicity in the alloy samples. By prolonging the reaction time, the $S$ content in the metal decreased. Additionally, increasing the slag basicity can also significantly lower the $\mathrm{S}$ content in the metal.

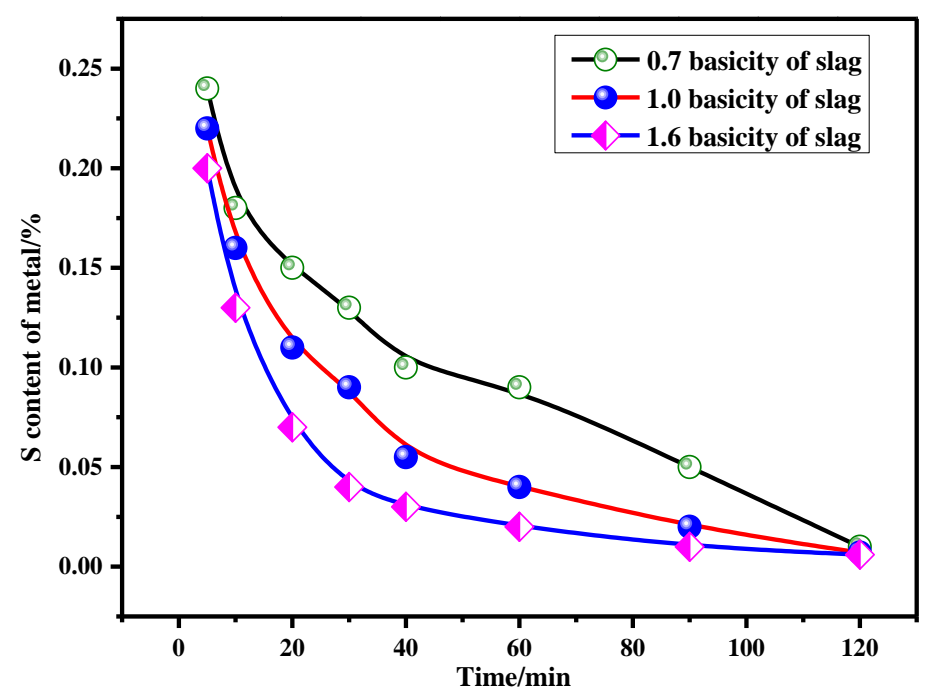

Figure 11. Effects of time and basicity on $\mathrm{S}$ content of metal (Smelting temperature $1550{ }^{\circ} \mathrm{C}$ ).

The plots of $I n \frac{[\% \mathrm{~S}]_{0}-[\% \mathrm{~S}]_{F}}{[\%]_{t}-[\% \mathrm{~S}]_{F}}$ with the reaction times of for different slag basicity are shown in Figure 12, indicating that the test dates $\left(\operatorname{In} \frac{[\% \mathrm{~S}]_{0}-[\% \mathrm{~S}]_{F}}{[\%]_{t}-[\% \mathrm{~S}]_{F}}\right)$ consist well with the theoretical curve in the smelting process at the various basicity's of slag. The standard deviation value of the fitted curves was all over 0.96 , which revealed that $I n \frac{[\% \mathrm{~S}]_{0}-[\% \mathrm{~S}]_{F}}{[\% \mathrm{~S}]_{t}-[\% \mathrm{~S}]_{F}} \sim t$ was a preferable linear relationship. Furthermore, it confirmed that the control process of the total desulfurization reaction was the mass transfer of [S] in the metal phase.

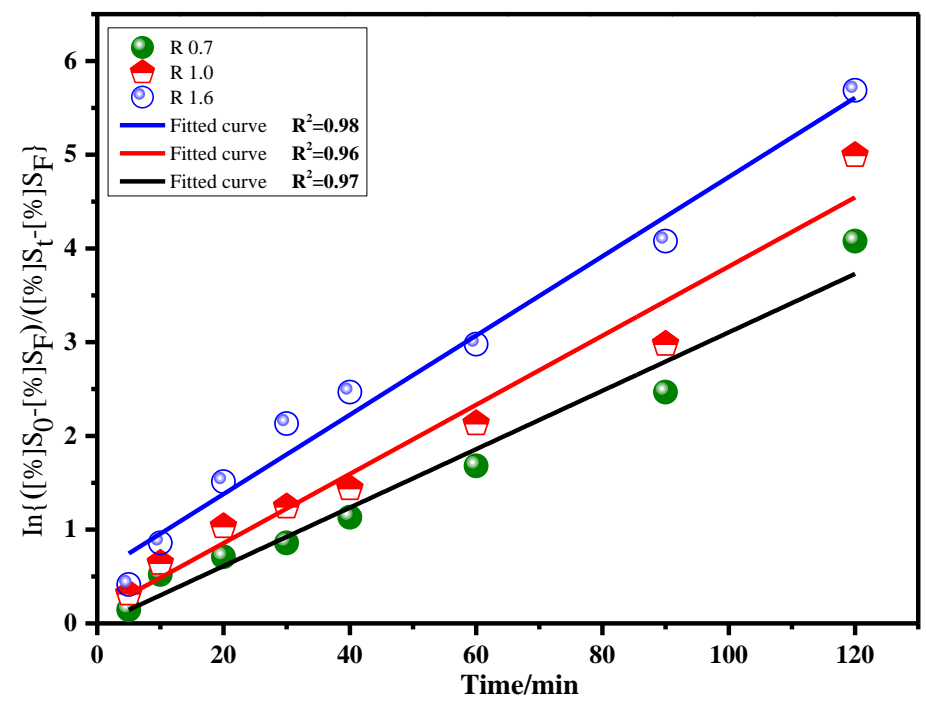

Figure 12. Relation curve between $\operatorname{In} \frac{[\% \mathrm{~S}]_{0}-[\% \mathrm{~S}]_{F}}{[\%]_{t}-[\% \mathrm{~S}]_{F}}$ and $t$.

According to the slope of the line for the fitted curves (as seen in Figure 12), the diffusion coefficient can be determined, and the results are shown in Table 3. The diffusion coefficient for desulfurization reaction of 0.7 basicity slag was $0.78 \times 10^{-3} \mathrm{~cm} / \mathrm{s}$, whereas increasing the basicity to 1.0 and 1.6, 
the diffusion coefficient elevated to $0.92 \times 10^{-3} \mathrm{~cm} / \mathrm{s}$ and $1.05 \times 10^{-3} \mathrm{~cm} / \mathrm{s}$, respectively. These results mean that the slag basicity can promote the mass transfer of $S$ in the slag phase and accelerate the progress of the desulfurization reaction. As a result, the higher basicity allows for better desulfurization efficiency and lower $\mathrm{S}$ content of the $\mathrm{Fe}-\mathrm{Cu}$ alloy.

Table 3. Diffusion coefficient of sulphur in alloy melt $(\mathrm{cm} / \mathrm{s})$.

\begin{tabular}{cccc}
\hline \multirow{2}{*}{ Items } & \multicolumn{3}{c}{ Basicity R } \\
\cline { 2 - 4 } & $\mathbf{0 . 7}$ & $\mathbf{1 . 0}$ & $\mathbf{1 . 6}$ \\
\hline Diffusion coefficient & $0.78 \times 10^{-3}$ & $0.92 \times 10^{-3}$ & $1.05 \times 10^{-3}$ \\
\hline
\end{tabular}

\subsection{Characterization of the $\mathrm{Fe}-\mathrm{Cu}$ Master Alloy}

The superior $\mathrm{Fe}-\mathrm{Cu}$ master alloy can be obtained under the optimum smelting conditions of $1550{ }^{\circ} \mathrm{C}, 40 \mathrm{~min}$ and 1.0 basicity. The chemical composition of the $\mathrm{Fe}-\mathrm{Cu}$ master alloy is shown in Table 4. The alloy contains $95.9 \% \mathrm{Fe}, 1.4 \% \mathrm{Cu}$ and some minor impurities. The total content of valuable metals is as high as $97.3 \%$. In addition, the $\mathrm{S}$ content of the master alloy decreased to $0.055 \%$. The final product can be used along with scrap steel for the preparation of $\mathrm{Cu}$-bearing steel by electric arc furnace.

Table 4. Chemical compositions of Fe-Cu master alloy (wt \%).

\begin{tabular}{ccccccccccc}
\hline $\mathbf{F e}$ & $\mathbf{C u}$ & $\mathbf{S}$ & $\mathrm{SiO}_{2}$ & $\mathrm{Al}_{2} \mathbf{O}_{3}$ & $\mathbf{C a O}$ & $\mathbf{M g O}$ & $\mathbf{N a}_{2} \mathbf{O}$ & $\mathbf{P}$ & $\mathbf{Z n}$ & $\mathbf{P b}$ \\
\hline 95.86 & 1.36 & 0.055 & 0.10 & 0.32 & 0.053 & 0.027 & 0.005 & 0.01 & 0.01 & 0.009 \\
\hline
\end{tabular}

Figure 13 shows the microstructures of master alloy and chemical compositions under SEM and EDS. These results show that the master alloy is very uniform and pure. Through EDS analysis of a micro zone, the alloy contains $98.6 \% \mathrm{Fe}$ and $1.4 \% \mathrm{Cu}$, and no obvious impurities were found, which further confirms the good performance of this master alloy.

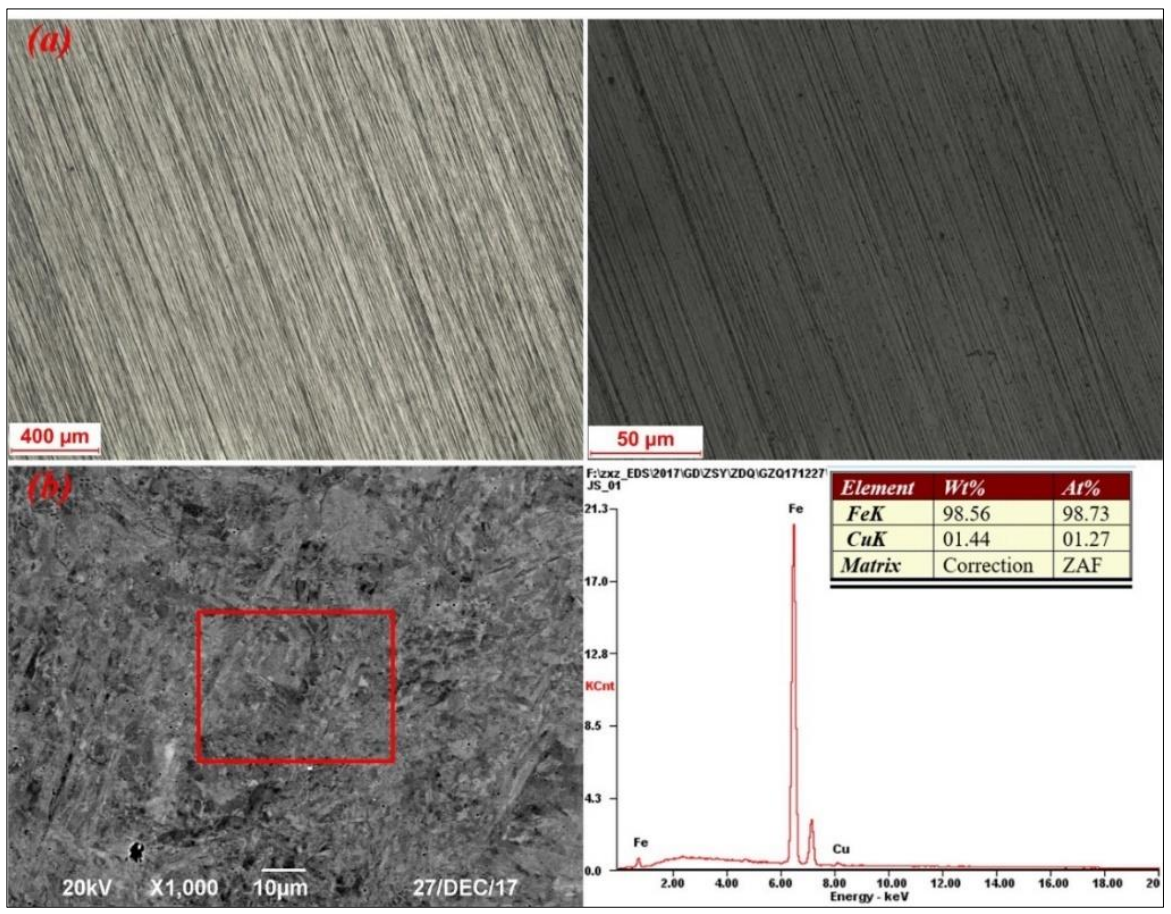

Figure 13. SEM-EDS and microstructure of $\mathrm{Fe}-\mathrm{Cu}$ alloy. 


\section{Conclusions}

Experimental studies for the smelting process of CBDRI to prepare the $\mathrm{Cu}$-bearing steel master alloy have been carried out in this work, and the mechanism of desulfurization was revealed as well. The following conclusions can be drawn:

(1) A high quality $\mathrm{Fe}-\mathrm{Cu}$ master alloy, assaying $95.9 \% \mathrm{Fe}, 1.4 \% \mathrm{Cu}$ and minor impurities, can be obtained from the smelting process under the optimum conditions of $1550{ }^{\circ} \mathrm{C}, 40 \mathrm{~min}$ and 1.0 basicity. The corresponding iron and copper recoveries are $98.6 \%$ and $97.2 \%$, respectively. Through the smelting process, the total metal content in the alloy was increased, and the $S$ content was significantly decreased to $0.05 \%$, which is beneficial to the production of clean steel. It also confirms the necessity of further smelting for CBDRI.

(2) Suitable basicity of the molten slag favours an increase in the recovery of $\mathrm{Fe}$ and $\mathrm{Cu}$, which results from a rise in the amount of liquid and the improvement in the slag fluidity. In particular, the optimum binary basicity is in the range of $0.9 \sim 1.1$.

(3) The theoretical calculation results show that the sulfur capacity of the slag elevated with the increasing temperature and basicity, which benefits the desulfurization efficiency. The desulfurization reaction kinetics show that increasing the slag basicity contributes to the diffusion coefficient of the sulfur in the molten slag.

Author Contributions: D.Z., Z.G. and J.P. conceived and designed the experiments; Z.G. and L.P. performed the experiments; Z.G. and L.P. wrote the paper; D.Z. modified the paper.

Funding: This research was funded by National Natural Science Foundation of China (No.51474161) and Innovation-driven Project of Guangxi Zhuang Autonomous Region (No. AA18242003, No. AA148242003).

Acknowledgments: The authors wish to express thanks to the National Natural Science Foundation of China (No. 51474161) for the financial support of this research, and also would like to thank Co-Innovation Center for Clean and Efficient Utilization of Strategic Metal Mineral Resources of Hunan Province, which supplied us the facilities and funds to fulfill the experiments.

Conflicts of Interest: The authors declare no conflict of interest.

\section{References}

1. Shi, X.B.; Yan, W.; Xu, D.K.; Yan, M.C.; Yang, C.G.; Shan, Y.Y.; Yang, K. Microbial corrosion resistance of a novel Cu-bearing pipeline steel. J. Mater. Sci. Technol. 2018, 34, 2480-2491. [CrossRef]

2. Cao, Z.Q.; Zhao, J.; Yang, K. Cu-bearing stainless steel reduces cytotoxicity and crystals adhesion after ureteral epithelial cells exposing to calcium oxalate monohydrate. Sci. Rep. 2018, 8. [CrossRef] [PubMed]

3. Zhang, X.R.; Zhao, J.L.; Xi, T.; Shahzad, M.B.; Yang, C.G.; Yang, K. Dissolution and repair of passive film on Cu-bearing 304L stainless steels immersed in $\mathrm{H}_{2} \mathrm{SO}_{4}$ solution. J. Mater. Sci. Technol. 2018, 34, 2149-2159. [CrossRef]

4. Morcillo, M.; Díaz, I.; Chico, B.; Cano, H.; Fuente, D. Weathering steels: From empirical development to scientific design. A review. Corros. Sci. 2014, 83, 6-31. [CrossRef]

5. Morcillo, M.; Chico, B.; Díaz, I.; Cano, H.; Fuente, D. Atmospheric corrosion data of weathering steels. A review. Corros. Sci. 2013, 77, 6-24. [CrossRef]

6. Ma, T.; Yang, G.Y.; Deng, M.L.; Liu, Y.G. Research Status and Prospect of Copper-bearing Steel. Hot Work. Technol. 2017, 46, 36-39. (In Chinese)

7. Shyi, W.; Powe, K. Effect of alloying elements on the structure and mechanical properties of ultra low carbon bainitic steels. Mater. Sci. 1993, 28, 5169-5175.

8. Guo, Z.Q.; Pan, J.; Zhu, D.Q.; Zhang, F. Co-reduction of Copper Smelting Slag and Nickel Laterite to Prepare Fe-Ni-Cu Alloy for Weathering Steel. JOM 2018, 70, 150-154. [CrossRef]

9. Li, S.W.; Pan, J.; Zhu, D.Q.; Guo, Z.Q.; Xu, J.W.; Chou, J.L. A novel process to upgrade the copper slag by direct reduction-magnetic separation with the addition of $\mathrm{Na}_{2} \mathrm{CO}_{3}$ and $\mathrm{CaO}$. Powder Technol. 2019, 347, 159-169. [CrossRef]

10. Guo, Z.Q.; Zhu, D.Q.; Pan, J.; Yao, W.J.; Xu, W.Q.; Chen, J.A. Effect of $\mathrm{Na}_{2} \mathrm{CO}_{3}$ Addition on Carbothermic Reduction of Copper Smelting Slag to Prepare Crude Fe-Cu Alloy. JOM 2017, 69, 1688-1695. [CrossRef] 
11. Gorai, B.; Jana, R.; Premchand, M. Characteristics and utilization of copper slag-a review. Resour. Conserv. Recycl. 2003, 39, 299-313. [CrossRef]

12. Subrata, R.; Amlan, D.; Sandeep, R. Flotation of copper sulphide from copper smelter slag using multiple collectors and their mixtures. Int. J. Miner. Process. 2015, 34, 43-49.

13. Guo, Z.Q.; Pan, J.; Zhu, D.Q.; Zhang, F. Green and efficient utilization of waste ferric-oxide desulfurizer to clean waste copper slag by the smelting reduction-sulfurizing process. J. Clean. Prod. 2018, 199, 891-899. [CrossRef]

14. Li, Y.; Perederiy, I.; Papangelakis, V.G. Cleaning of waste smelter slags and recovery of valuable metals by pressure oxidative leaching. J. Hazard. Mater. 2008, 152, 607-615. [CrossRef] [PubMed]

15. Shibayama, A.; Takasaki, Y.; William, T.; Yamatodani, A.; Higuchi, Y.; Sunagawa, S.; Ono, E. Treatment of smelting residue for arsenic removal and recovery of copper using pyro-hydrometallurgical process. J. Hazard. Mater. 2010, 181, 1016-1023. [CrossRef] [PubMed]

16. Perederiy, I.; Papangelakis, V.G.; Buarzaiga, M.; Mihaylov, I. Co-treatment of converter slag and pyrrhotite tailings via high pressure oxidative leaching. J. Hazard. Mater. 2011, 194, 399-406. [CrossRef]

17. Antonijevic, M.M.; Dimitrijevic, M.D.; Stevanovic, Z.O.; Serbula, S.M.; Bogdanovic, G.D. Investigation of the possibility of copper recovery from the flotation tailings by acid leaching. J. Hazard. Mater. 2008, 152, $23-34$. [CrossRef]

18. Zuo, Z.L.; Yu, Q.B.; Xie, H.Q.; Wang, K.; Liu, S.H.; Yang, F.; Qin, Q.; Qi, Z.F. Mechanical and reduction characteristics of cold-pressed copper slag pellets composited within biomass and lignite. Renew. Energy 2018, 125, 206-224. [CrossRef]

19. Guo, Z.Q.; Zhu, D.Q.; Pan, J.; Zhang, F. Innovative methodology for comprehensive and harmless utilization of waste copper slag via selective reduction-magnetic separation process. J. Clean. Prod. 2018, 187, 910-922. [CrossRef]

20. Chun, T.; Mu, G.; Di, Z.; Long, H.; Ning, C.; Li, D. Recovery of iron from copper slag by carbothermic thermic reduction and magnetic separation in the presence of CaO. Arch. Metall. Mater. 2018, 63, 299-305.

21. Geng, C.; Wang, H.J.; Hu, W.T.; Li, L.; Shi, C.S. Recovery of iron and copper from copper tailings by coal-based direct reduction and magnetic separation. J. Iron Steel Res. Int. 2017, 24, 991-997. [CrossRef]

22. Jiao, R.M.; Xing, P.; Wang, C.Y.; Ma, B.Z.; Chen, Y.Q. Recovery of iron from copper tailings via low-temperature direct reduction and magnetic separation: Process optimization and mineralogical study. Int. J. Min. Met. Mater. 2017, 24, 974-982. [CrossRef]

23. Wang, X.H. Ferrous Metallurgy (Steelmaking Part), 1st ed.; Metallurgical Industry Press: Beijing, China, 2007. (In Chinese)

24. Liu, Y.; Lv, X.; Xu, J.; Zhang, S.; Bai, C. Preparation of stainless steel master alloy by direct smelting reduction of Fe-Ni-Cr Sinter at $1600^{\circ} \mathrm{C}$. Ironmak. Steelmak. 2016, 8, 1-7. [CrossRef]

25. Yan, Z.; Lv, X.; Pang, Z.; He, W.; Liang, D.; Bai, C. Transition of Blast Furnace Slag from Silicate Based to Aluminate Based: Sulfide Capacity. Metall. Mater. Trans. B 2017, 48, 2607-2613. [CrossRef]

26. Guo, H. Metallurgical Physical Chemistry, 2nd ed.; China Metallurgical Industry Press: Beijing, China, 2012. (In Chinese)

27. Young, R.W.; Duffy, J.A.; Hassall, G.J. Use of optical basicity concept of determining phoshphorus and sulfur slag-metal partitions. Ironmak. Steelmak. 1992, 19, 201-209.

28. Wang, L.; Wu, S.; Kou, M.; Du, B.; Lu, Y.; Gu, K. Improving the Desulphurization in COREX Process by Adjusting the Hot Metal Chemical Composition. Metall. Mater. Trans. B 2018, 49, 89-96. [CrossRef]

29. Wang, X.L. Ferrous Metallurgy (Ironmaking Part), 3rd ed.; China Metallurgical Industry Press: Beijing, China, 2013. (In Chinese)

30. Kang, J.G.; Shin, J.H.; Chung, Y.; Park, J.H. Effect of Slag Chemistry on the Desulfurization Kinetics in Secondary Refining Processes. Metall. Mater. Trans. B 2017, 48, 2123-2135. [CrossRef]

31. Peter, J.; Peaslee, K.D.; Robertson, D.G.C.; Thomas, B.G. Proceedings of the AISTech 2005; AIST: Warrendale, PA, USA, 2005; pp. 959-967.

32. Robertson, D.G.C.; Staples, B.B. Process Engineering of Pyrometallurgy; IMM: London, UK, 1974; pp. 51-59.

(C) 2019 by the authors. Licensee MDPI, Basel, Switzerland. This article is an open access article distributed under the terms and conditions of the Creative Commons Attribution (CC BY) license (http://creativecommons.org/licenses/by/4.0/). 